\title{
Evidence for Abnormal Forward Trafficking of AMPA Receptors in Frontal Cortex of Elderly Patients with Schizophrenia
}

\author{
John C Hammond ${ }^{*, 1,2}$, Robert E McCullumsmith ${ }^{2}$, Adam J Funk ${ }^{1,2}$, Vahram Haroutunian ${ }^{3}$ \\ and James $\mathbf{H}$ Meador-Woodruff ${ }^{2}$ \\ 'Department of Neurobiology, University of Alabama Birmingham, Birmingham, AL, USA; ${ }^{2}$ Department of Psychiatry and Behavioral \\ Neurobiology, University of Alabama Birmingham, Birmingham, AL, USA; ${ }^{3}$ Department of Psychiatry, Mount Sinai School of Medicine, New York, \\ NY, USA
}

Several lines of evidence point to alterations of $\alpha$-amino-3-hydroxyl-5-methyl-4-isoxazole-propionate (AMPA) receptor trafficking in schizophrenia. Multiple proteins, including synapse-associated protein 97 (SAP97), glutamate receptor-interacting protein I (GRIPI), and $\mathrm{N}$-ethylmaleimide sensitive factor (NSF), facilitate the forward trafficking of AMPA receptors toward the synapse. Once localized to the synapse, AMPA receptors are trafficked in a complex endosomal system. We hypothesized that alterations in the expression of these proteins and alterations in the subcellular localization of AMPA receptors in endosomes may contribute to the pathophysiology of schizophrenia. Accordingly, we measured protein expression of SAP97, GRIPI, and NSF in the dorsolateral prefrontal cortex and found an increase in the expression of SAP97 and GRIPI in schizophrenia. To determine the subcellular localization of AMPA receptor subunits, we developed a technique to isolate early endosomes from post-mortem tissue. We found increased GluRI receptor subunit protein in early endosomes in subjects with schizophrenia. Together, these data suggest that there is an alteration of forward trafficking of AMPA receptors as well as changes in the subcellular localization of an AMPA receptor subunit in schizophrenia.

Neuropsychopharmacology (2010) 35, 21 10-21 19; doi:I0.1038/npp.2010.87; published online 23 June 2010

Keywords: schizophrenia; endosome; EEAI; AMPA trafficking; post mortem

\section{INTRODUCTION}

There is a growing body of evidence that schizophrenia may be linked to abnormalities of glutamate transmission. While early evidence implicated NMDA receptor hypofunction (Allen and Young, 1978; Barbon et al, 2007; Coyle et al, 2003; Ellison, 1995), preclinical literature has also implicated involvement of $\alpha$-amino-3-hydroxyl-5-methyl-4-isoxazolepropionate (AMPA) receptors in the pathophysiology of this illness (Dracheva et al, 2005; Meador-Woodruff et al, 2001; O'Connor et al, 2007). Several studies have examined AMPA receptor expression in multiple brain regions with inconsistent results (Breese et al, 1995; Eastwood et al, 1995; Freed et al, 1993; Healy et al, 1998; Noga et al, 2001; Scarr et al, 2005). Measuring total AMPA receptor expression levels may be less informative, however, since AMPA receptors are highly regulated through trafficking between

*Correspondence: JC Hammond, Department of Neurobiology, University of Alabama Birmingham, CIRC 586, 1719 6th Avenue S., Birmingham, AL 35294-002I, USA, Tel: + 205996 6356, Fax: + 205 975 4879, E-mail: hammondj@uab.edu

Received 28 April 2010; revised 20 May 20 I0; accepted 24 May 2010 subcellular organelles from the endoplasmic reticulum to localization at the synapse (Greger and Esteban, 2007; Jiang et al, 2006; Zhu, 2003). Measurement of total cellular AMPA receptor expression cannot distinguish localization in these subcellular compartments, yet abnormalities in subcellular localization may have significant functional implications.

The lack of consistent findings and the complexity of AMPA receptor trafficking have led to the examination of proteins that interact with AMPA receptors. Several interacting proteins, including synapse-associated protein 97 (SAP97), glutamate receptor-interacting protein 1 (GRIP1), and $N$-ethylmaleimide sensitive factor (NSF) have a significant role in the trafficking and localization of AMPA receptors. SAP97 interacts with the AMPA receptor subunit GluR1 and the myosin motor protein responsible for transport of the receptor along the dendritic shaft (Wu et al, 2002). SAP97 has also been described in the stabilization of GluR1-containing AMPA receptors at the synapse (Nash et al, 2010). GRIP1 interacts with the AMPA receptor subunit GluR2 and assists in the transport of the AMPA receptor along the dendritic shaft and stabilization at the synapse (Guo and Wang, 2007). NSF helps regulate surface expression of GluR2-containing AMPA receptors 
(Noel et al, 1999). As a result of the complexity of AMPA receptor trafficking, these molecules are potential candidates to study in schizophrenia.

Studies have found alterations in proteins associated with forward trafficking of AMPA receptors in schizophrenia (Beneyto and Meador-Woodruff, 2006; Mirnics et al, 2000; Toyooka et al, 2002; Whiteheart and Matveeva, 2004). Transcripts and protein for SAP97 were decreased in the prefrontal cortex, but not the hippocampus or occipital cortex, suggesting a region specific deficit in AMPA receptor trafficking (Toyooka et al, 2002). Two other studies found decreases in NSF mRNA levels in the prefrontal cortex (Mirnics et al, 2000; Whiteheart and Matveeva, 2004) possibly indicating a problem with AMPA receptor recycling at the synapse, which is facilitated by endosomes. These abnormalities in the proteins specifically involved in the forward trafficking of AMPA receptors suggest that endosomal trafficking of this receptor may be abnormal in schizophrenia.

Endosomal trafficking of neurotransmitter receptors facilitates changes in synaptic strength through surface expression and localization of receptors to the synapse, as well as degradation of receptors. The endocytic pathway and the turnover of AMPA receptors have been extensively studied in the context of long-term potentiation (LTP) and long-term depression (LTD), correlates of learning and memory that may be affected in psychiatric illness. Endosomes are small (approximately $1 \mu \mathrm{m}$ ) spherical structures with a phospholipid bilayer that facilitate sorting of AMPA receptors between intracellular compartments and the cell surface (Beattie et al, 2000; Boehm et al, 2006; Lüscher et al, 1999). Subclasses of endosomes are identified by the presence or absence of specific marker proteins, such as early endosome antigen-1 (EEA1), Rab7, and Rab11 (Carroll et al, 1999; Ehlers, 2000; Gerges et al, 2004). Each subclass of endosome has a particular morphology and role in the trafficking of proteins (Ehlers, 2000; Lee et al, 2004; Park et al, 2004; Tjelle et al, 1996). Early endosomes, containing EEA1, are the primary subclass that receives proteins endocytosed from the cell surface. From the early endosomes, proteins are sorted to recycling endosomes, containing Rab11, or late endosomes, containing Rab7, for degradation.

We hypothesized that forward trafficking and endosomal handling of AMPA receptors may be associated with the pathophysiology of schizophrenia. To test this, we measured expression of proteins associated with forward trafficking of AMPA receptors in brains from subjects with schizophrenia and a comparison group. In addition, we developed a technique to isolate intact early endosomes from post-mortem brain tissue, characterized the isolated early endosomes, and measured the expression of AMPA receptor subunits and trafficking molecules in endosomes from these same subjects.

\section{MATERIALS AND METHODS}

\section{Subjects and Tissue Preparation}

Subjects from the Mount Sinai Medical Center brain bank were recruited prospectively and underwent extensive antemortem diagnostic and clinical assessment (Table 1 and Supplementary Table 1). Exclusion criteria included a history of alcoholism, substance abuse, death by suicide, or coma for $>6 \mathrm{~h}$ before death. Consent was obtained from next of kin for each subject. Brains were collected and cut coronally in $10 \mathrm{~mm}$ slabs. The dorsolateral prefrontal cortex was dissected from the coronal slabs, snap frozen, and stored at $-80{ }^{\circ} \mathrm{C}$. This tissue was pulverized, adding small amounts of liquid nitrogen as necessary, and stored at $-80{ }^{\circ} \mathrm{C}$ until used.

Tissue was prepared for western blots as previously described (Funk et al, 2009). Tissue was reconstituted in $5 \mathrm{mM}$ Tris- $\mathrm{HCl} \mathrm{pH} 7.4,0.32 \mathrm{M}$ sucrose, and a protease inhibitor tablet (Complete Mini, Roche Diagnostics, Mannheim, Germany). Tissue was homogenized using a Power Gen 125 homogenizer (Thermo Fisher Scientific, Rockford, Illinois) at speed 5 for $60 \mathrm{~s}$. Homogenates were assayed for protein concentration using a BCA protein assay kit (Thermo Scientific, Rockford, Illinois), and stored at $-80^{\circ} \mathrm{C}$.

\section{Western Blot Analysis}

Commercially available antibodies were used for the western blot analyses with antisera dilutions determined empirically (Table 2). Samples for western blots were placed in reducing buffer-containing $\beta$-mercaptoethanol and heated at $70^{\circ} \mathrm{C}$ for $10 \mathrm{~min}$. Samples for each subject were then run in duplicate by SDS-polyacrylamide gel electrophoresis on Invitrogen (Carlsbad, California) 4-12\%

Table I Subject Demographics

\begin{tabular}{|c|c|c|c|c|}
\hline & \multicolumn{2}{|c|}{ Homogenate studies } & \multicolumn{2}{|c|}{ Endosome studies } \\
\hline & Comparison & Schizophrenia & Comparison & Schizophrenia \\
\hline Sex & $12 \mathrm{~m} / 19 \mathrm{f}$ & $23 \mathrm{~m} / 12 \mathrm{f}$ & $8 \mathrm{~m} / 13 \mathrm{f}$ & $15 \mathrm{~m} / 5 \mathrm{f}$ \\
\hline Tissue $\mathrm{pH}$ & $6.4 \pm 0.2$ & $6.4 \pm 0.3$ & $6.4 \pm 0.3$ & $6.4 \pm 0.3$ \\
\hline Medication (on/off) & $0 / 31$ & $24 / 11$ & $0 / 21$ & $12 / 8$ \\
\hline
\end{tabular}

Abbreviations: $f$, female; $m$, male; PMI, post-mortem interval.

Values presented as mean \pm SD. 


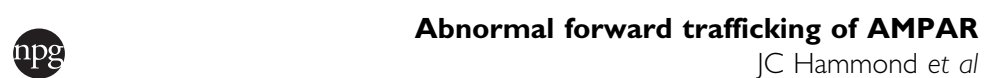

Table 2 Antibodies Used for Western Blot Studies

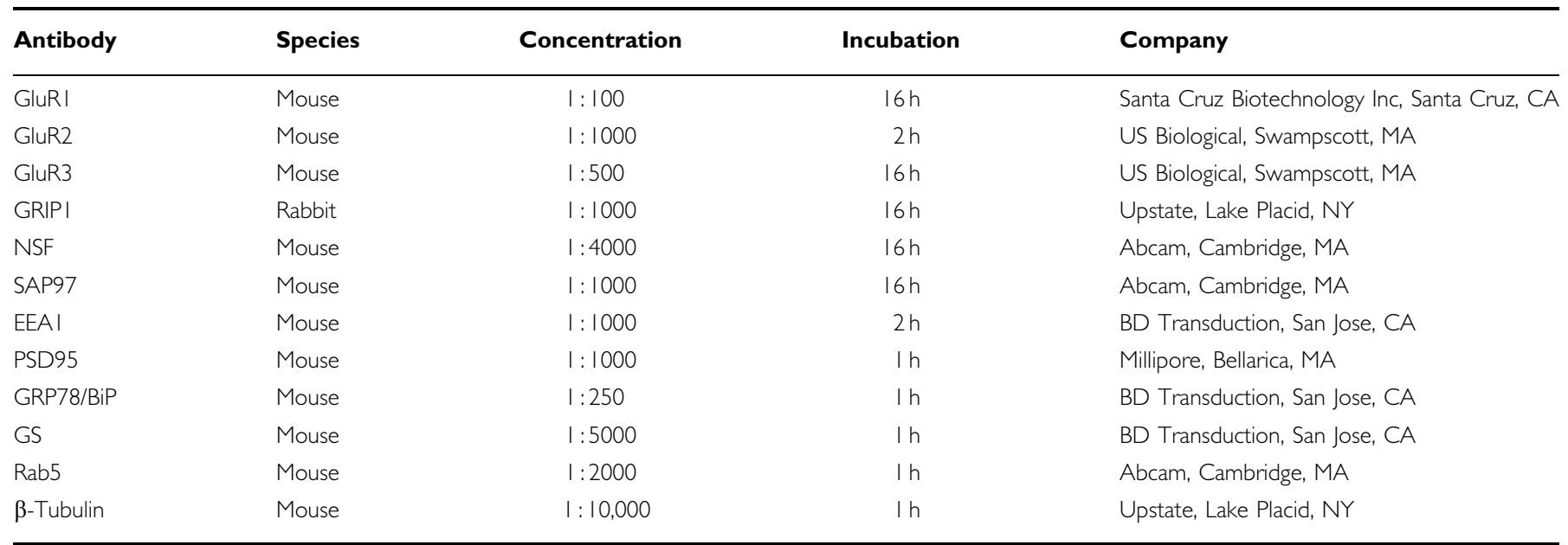

Abbreviations: EEAI, early endosome antigen I; GluR, glutamate receptor; GRIPI, glutamate receptor-interacting protein I, GRP78/BiP, glucose-regulated protein 78/binding protein; GS, glutamine synthetase; NSF, N-ethylmalemide sensitive factor; PSD95, postsynaptic density 95; SAP97, synapse-associated protein 97.

gradient gels, and transferred to polyvinylidene fluoride membrane using Bio-Rad semi-dry transblotter (Hercules, California). The membranes were blocked in LiCor (Lincoln, Nebraska) blocking buffer for $1 \mathrm{~h}$ at room temperature, and probed with primary antibody in $0.1 \%$ Tween LiCor blocking buffer at the dilutions and for the durations indicated in Table 2. Membranes were then washed four times for $5 \mathrm{~min}$ each with $0.01 \%$ Tween phosphate-buffered saline. Membranes were probed with IR-dye labeled secondary antibody in $0.1 \%$ Tween, $0.01 \%$ SDS LiCor blocking buffer for $1 \mathrm{~h}$ at room temperature in the dark. Membranes were washed again with $0.01 \%$ Tween phosphate-buffered saline four times for $5 \mathrm{~min}$ each and then briefly rinsed three times in distilled water. The blots were stored in distilled water at $4{ }^{\circ} \mathrm{C}$ until scanned using the LI-COR Odyssey laser-based image detection method (Bond et al, 2008). We tested each antibody using varying concentrations of total protein from homogenized human cortical tissue to confirm we were in the linear range of the assay.

\section{Immunoisolation of Early Endosomes}

A subset of subjects (Table 1) was used for early endosome isolation because of the large amounts of tissue required for this technique. For each subject, isolation was performed in duplicate. In total, $80 \mu \mathrm{l}\left(6.7 \times 10^{8}\right.$ beads $\left./ \mathrm{ml}\right)$ of sheep antirabbit Dynabead M280 magnetic beads (Invitrogen) were washed three times with ice-cold phosphate-buffered saline. All washes consisted of $5 \mathrm{~min}$ rotating at $4{ }^{\circ} \mathrm{C}$ and $2 \mathrm{~min}$ on the magnet (Dynal MPC-S, Invitrogen). Beads were then resuspended in $70 \mu \mathrm{l}$ of phosphate-buffered saline and $7.5 \mu \mathrm{g}$ of rabbit anti-EEA1 antibody (Abcam, Cambridge, Massachusetts). The bead-antibody solution was incubated while rotating at $4{ }^{\circ} \mathrm{C}$ for $16-18 \mathrm{~h}$ to form a bead-antibody complex. In all, $70 \mu \mathrm{l}$ of fresh beads were chilled on ice and washed three times with ice-cold phosphate-buffered saline. We added $130 \mu \mathrm{g}$ of homogenized tissue in $5 \mathrm{mM}$ Tris- $\mathrm{HCl}$ (final volume $200 \mu \mathrm{l}$ ) to the freshly washed beads, and precleared the tissue for $1 \mathrm{~h}$ while rotating at $4{ }^{\circ} \mathrm{C}$. The beadantibody complex was washed three times with ice-cold phosphate-buffered saline. After the 1-h incubation, the precleared tissue homogenate was collected and incubated with the bead-antibody complex for $3 \mathrm{~h}$ while rotating at $4{ }^{\circ} \mathrm{C}$ to isolate early endosomes. The supernatant of the bead-antibody-endosome complex was collected and saved, and the bead-antibody-endosome complex was washed three times with ice-cold phosphate-buffered saline. This complex was reconstituted in $20 \mu \mathrm{l}$ of distilled Milli-Q water and samples were prepared for western blot analysis or electron microscopy. Samples for western blot analysis were heated in reducing buffer-containing $\beta$-mercaptoethanol at $70{ }^{\circ} \mathrm{C}$ for $10 \mathrm{~min}$. Samples were placed in the Dynal magnet for $2 \mathrm{~min}$ before loading on the gel.

\section{Electron Microscopy}

Immediately after immunoisolation and reconstitution in Milli-Q water, bead-antibody-endosome complexes were embedded in agarose and then fixed with $4 \%$ glutaraldehyde in $0.1 \mathrm{M}$ cacodylate buffer ( $\mathrm{pH} 7.4$ ) overnight at room temperature. The complexes were then washed and treated with $1 \%$ osmium tetroxide for $1 \mathrm{~h}$, mordanted with $0.25 \%$ uranyl acetate in acetate buffer for $30 \mathrm{~min}$ to overnight, washed and dehydrated with a graded series of ethanol washes and propylene oxide. Finally, the samples were embedded in epoxy resin, thin sectioned and counterstained with uranyl acetate and lead citrate. Images were captured using an FEI Tecnai Spirit 20-120kv Transmission Electron Microscope.

\section{Data Analysis}

Near-infrared fluorescent signals obtained from the LiCor Odyssey scanner were expressed as raw integrated intensity with top-bottom median intralane background subtraction using Odyssey 3.0 analytical software (LiCor) (Bond et al, 2008). For homogenate protein studies, duplicate lanes of 
protein expression from each subject were normalized to $\beta$-tubulin as an in-lane loading control. $\beta$-Tubulin was chosen because no changes have previously been detected in subjects with schizophrenia compared with control subjects (Bauer et al, 2009). For immunoisolation studies, duplicate lanes of protein expression from each subject were normalized to EEA1 as an in-lane loading control.

To confirm the immunocapture of endosomes and to assess capture efficiency, 1650X direct magnification electron micrograph images of preclear, negative control, and immunoisolation samples, were printed, coded, and randomly sorted. Counts were made by an observer blind to condition. Beads or endosomes on the borders of each image were not included in the counts.

Data were analyzed using Statistica (Statsoft, Tulsa, Oklahoma). Correlation analyses were carried out to identify any associations between the dependent variables and $\mathrm{pH}$, age, and post-mortem interval. One-way analysis of covariance was performed if significant correlations were found. If no correlations were present, data were analyzed with one-way analysis of variance. Secondary analyses were performed using sex and medication status as the independent measure.
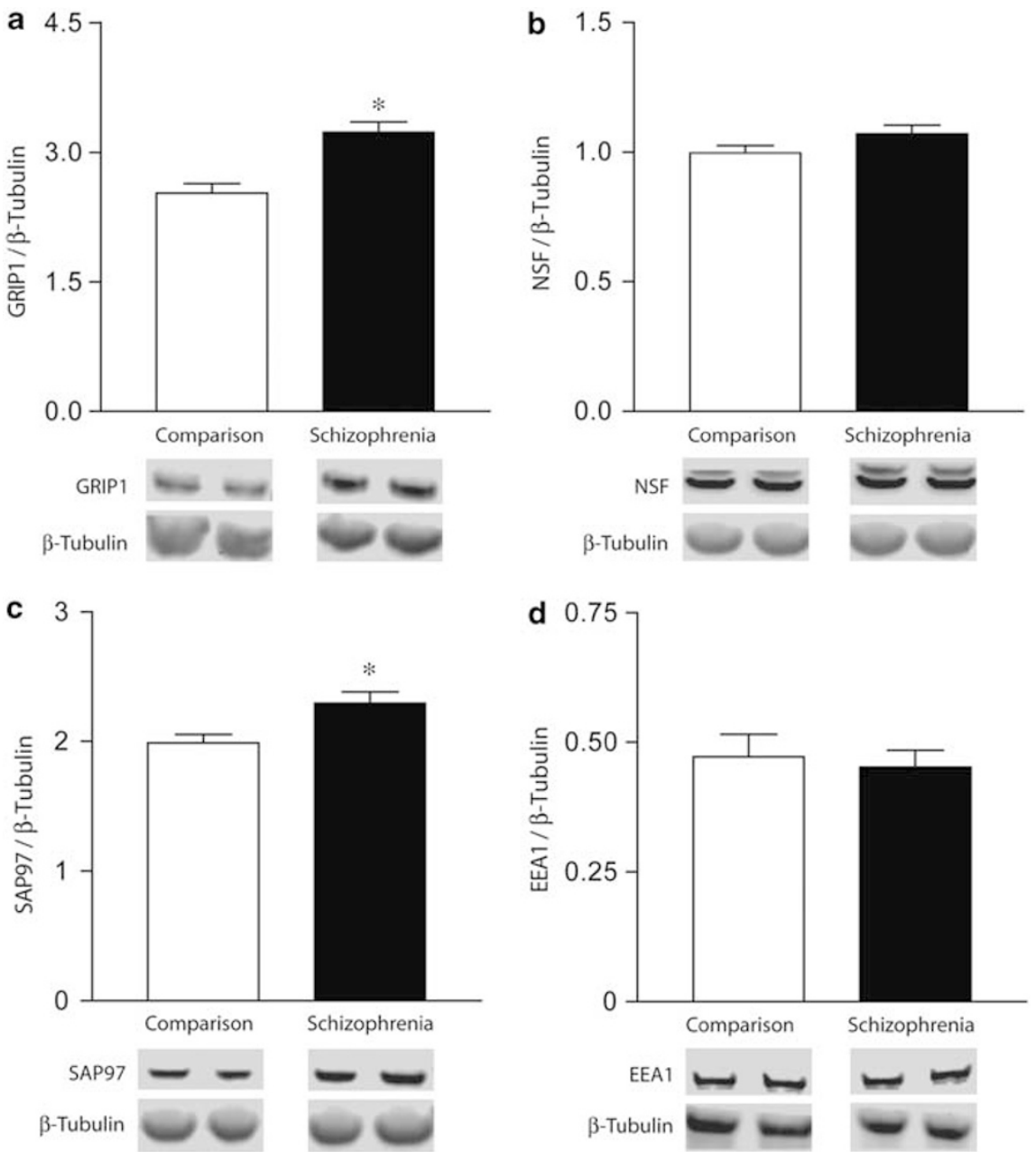

Figure I Western blot analysis of AMPA-interacting proteins ((a) - GRIPI, (b) -NSF, (c) - SAP97, and (d) -EEAI) in total brain homogenate normalized to $\beta$-tubulin. $* p<0.05$

\section{RESULTS}

\section{Protein Expression in Tissue Homogenates}

We examined the expression of the AMPA receptorinteracting proteins GRIP1, NSF, and SAP97 in schizophrenia and a comparison group using $\beta$-tubulin as a loading control (Figure 1). As previously reported (Bauer et al, 2009), we found no changes in $\beta$-tubulin (nonnormalized) in schizophrenia. In spite of a significant difference in PMI between the schizophrenia and comparison group $(\mathrm{F}(1,63)=6.59, p=0.01)$, we found no significant correlation between PMI and protein expression for GRIP1 $(\mathrm{F}(1,55)=1.32, p=0.26)$, SAP97 $(\mathrm{F}(1,54)=1.76$, $p=0.19)$, or NSF $(\mathrm{F}(1,53)=0.008, p=0.92)$. We also found no significant correlations between protein expression and age or $\mathrm{pH}$ in our samples. In addition, we found no effect of either sex or medication status in these homogenate studies. We found significant increases in GRIP1 $(\mathrm{F}(1,62)=18.659$, $p<0.01)$ and SAP97 $(\mathrm{F}(1,62)=7.719, p<0.01)$, but not NSF $(\mathrm{F}(1,62)=2.616, p=0.11)$ in subjects with schizophrenia. We also found no significant difference in the expression of EEA1 $(\mathrm{F}(1,52)=0.135, p=0.71)$, the marker we used to isolate early endosomes. We also examined total expression 
of GluR1-3 and found no change in schizophrenia (data not shown). We found a significant correlation between GluR1 and SAP97 expression in schizophrenia $(F(1,29)=5.29$, $p=0.03$ ), but not in our comparison group. We found no correlation between GluR2 and GRIP1 in either diagnostic group.

\section{Early Endosome Enrichment}

To analyze alterations in early endosome content in schizophrenia, we used magnetic beads bound to an early endosome-specific antibody to obtain an enriched early endosome fraction from post-mortem tissue (Figure 2). When starting with tissue homogenate, we detected nonspecific binding of PSD95 to our magnetic beads (Figure 2, non-precleared, IM, pellet lane). We incubated tissue with fresh beads to preclear the homogenate (Figure 2, preclear bead lane). Using this precleared tissue, we performed an immunoisolation (Figure 2, IM) with beads complexed to the EEA1 antibody. The negative control (Figure 2, - control) consists of precleared homogenate with beads alone. When starting with the precleared samples, we found markedly diminished nonspecific expression of PSD95 in our endosome preparation, while EEA1 protein levels were preserved (Figure 2, precleared, IM, pellet lane). Substituting preimmune IgG for the EEA1 capture antibody gave identical results as beads alone (data not shown).

Using electron microscopy, we measured the number of endosomes per bead in preclear, negative control, and immunoisolation samples. We found a 6.15-fold increase in the endosome to bead ratio in our immunoisolation samples relative to our preclear beads samples (Figure 3, Table 3).
To verify the specificity of our immunoisolation, we used western blot analysis to measure expression of proteins not expected to be expressed in early endosomes, including those found in the postsynaptic density (PSD95), endoplasmic reticulum (GRP78/BiP), astrocytes (glutamine synthetase), and late endosomes (Rab7). As anticipated, we did not find any of these markers in our early endosome preparation (Figure 4).

\section{Protein Expression in Early Endosomes}

We examined the expression of the AMPA receptor subunits, GluR1 - 3, in early endosomes samples (Figure 5). All protein expression was measured relative to EEA1 expression in the same lane. We found a significant increase in GluR1 $(\mathrm{F}(1,37)=4.189, p=0.048)$, but not GluR2 $(\mathrm{F}(1,41)=0.030, \quad p=0.864) \quad$ or GluR3 $(\mathrm{F}(1,41)=0.067$, $p=0.797)$ in the enriched endosome fraction. We found no significant correlations between protein expression and age, $\mathrm{pH}$, or $\mathrm{PMI}$ in our isolated endosome samples. In addition, we found no influence of sex in our isolated endosome studies.

Further analyses were carried out to determine if medication status had an effect on the expression of AMPA receptor subunits in early endosome isolation samples (Figure 6). We found a significant increase in GluR1 $(\mathrm{F}(2,36)=6.65, p=0.004)$, but not GluR2 $(\mathrm{F}(2,40)=1.92$, $p=0.159)$ or GluR3 $(\mathrm{F}(2,40)=0.13, p=0.876)$ in the enriched endosome fraction for patients off medication for 6 weeks or more before death compared with the comparison group $(p=0.003)$ or patients on medication 6 weeks or less before death $(p=0.018)$.

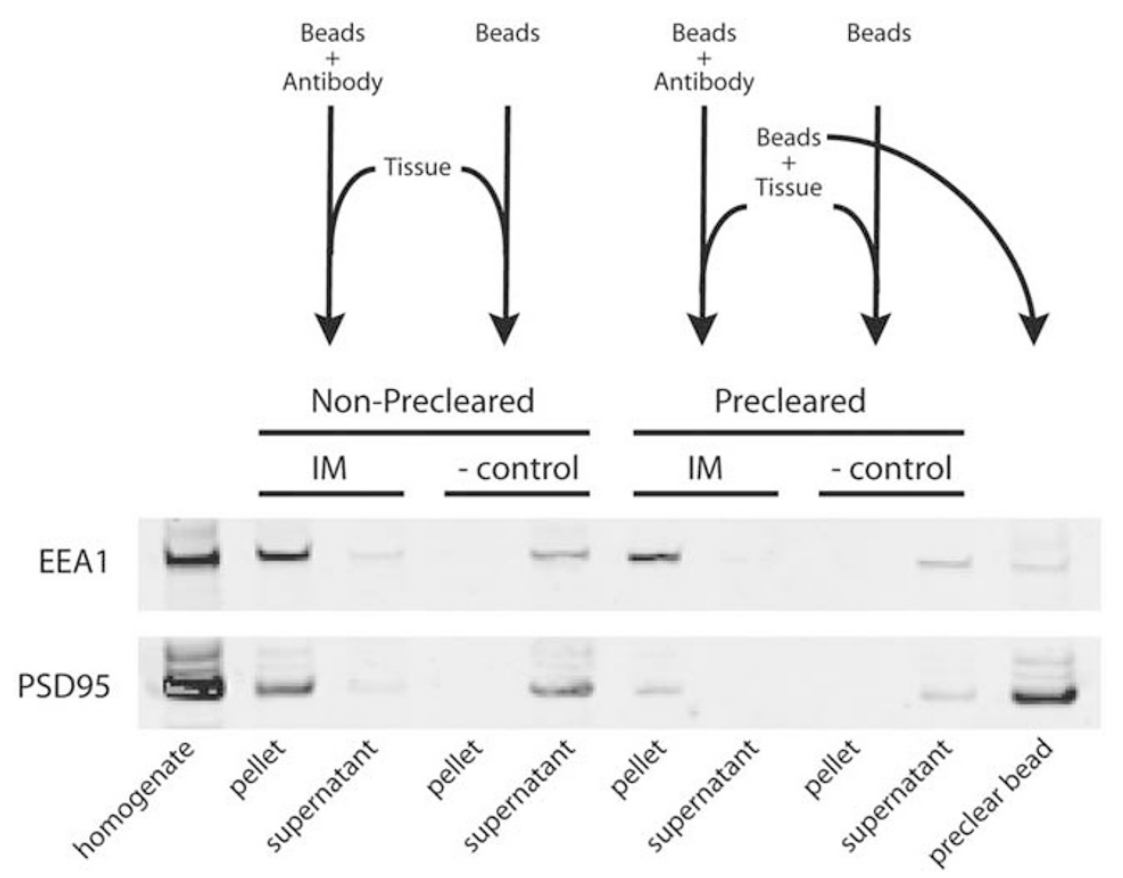

Figure 2 Flow chart of EEAI immunoisolation protocol with non-precleared and precleared tissue. Western blotting was used to determine protein expression of EEAI and PSD95. Nonspecific binding of PSD95 in EEAI immunoisolation is present with non-precleared tissue (non-precleared, IM, pellet lane). EEAI immunoisolation with precleared tissue has markedly reduced expression of PSD95 but maintains EEAI expression (precleared, IM, pellet lane). PSD95 sticks nonspecifically to beads (preclear bead lane). IM, immunoisolation; - control, negative control. 


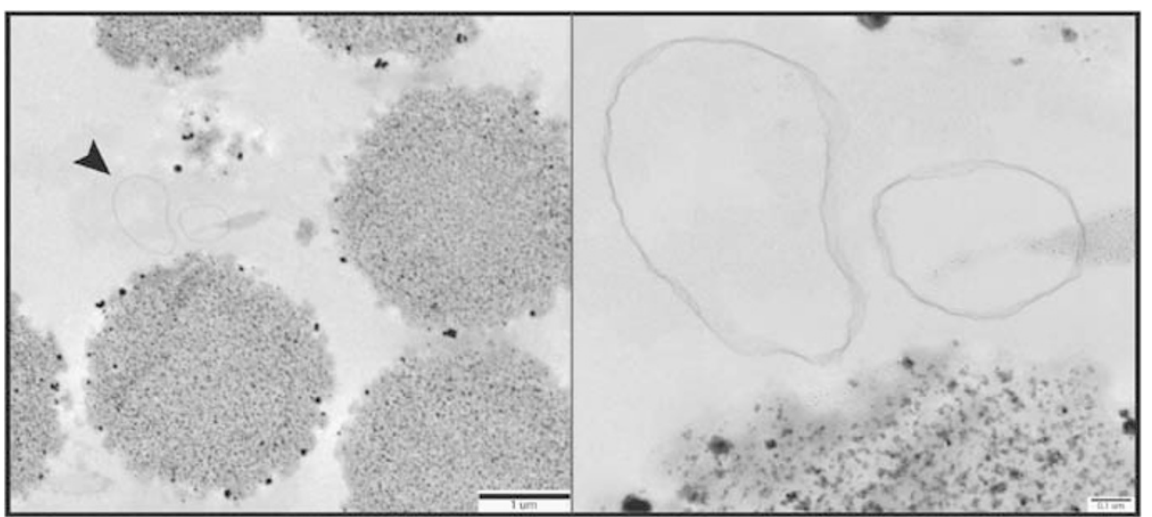

Figure 3 Electron micrograph of early endosome immunoisolation. Early endosomes were isolated using magnetic beads and EEAI capture antibody and imaged using electron microscopy. The panel on the right is an enlarged view of the area indicated by the arrow on the left.

Table 3 Endosome Counts from Electron Micrograph Studies

\begin{tabular}{llcc}
\hline Condition & Antibody & $\begin{array}{c}\text { Beads } \\
\text { counted }\end{array}$ & $\begin{array}{c}\text { Endosomes/ } \\
\text { bead }\end{array}$ \\
\hline Preclear (nonspecific binding) & None & 890 & 0.047 \\
Negative control & Rabbit lgG & 175 & 0.000 \\
Immunoisolation (specific binding) & Rabbit $\alpha$ EEAI & 560 & 0.276
\end{tabular}

Abbreviation: EEAI, early endosome antigen I.

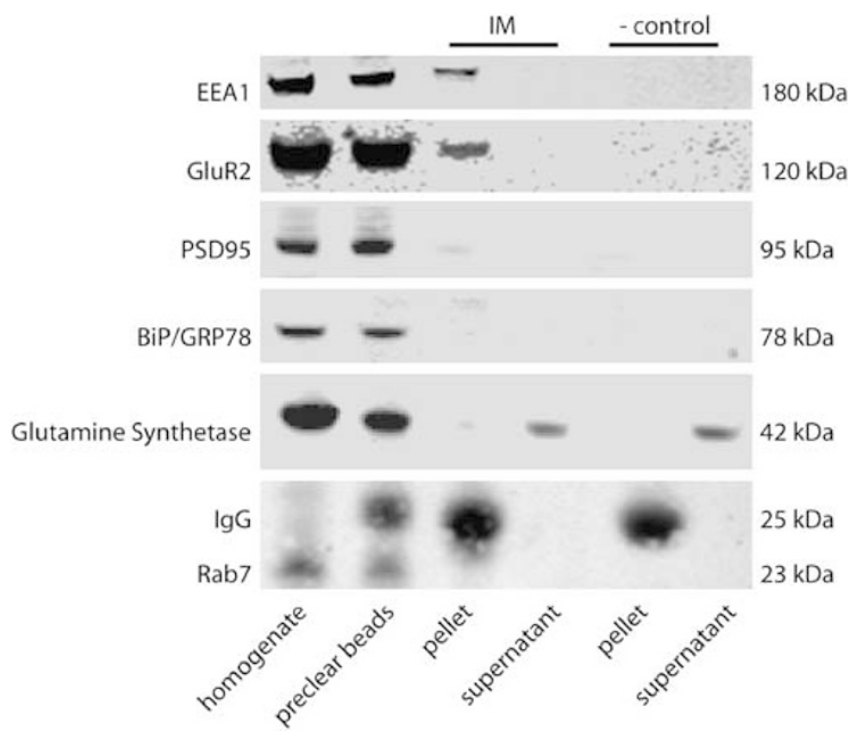

Figure 4 Characterization of early endosome isolation by western blot analysis. Proteins not expressed in early endosomes (IM-pellet) include those found in the postsynaptic density (PSD95), endoplasmic reticulum (GRP78/BiP), astrocytes (glutamine synthetase), and late endosomes (Rab7). Expression of the AMPA receptor subunit (GluR2) is present in early endosomes (IM-pellet). IM, immunoisolation; - control, negative control; EEAI, early endosome antigen I; PSD95, postsynaptic density 95; GRP78/BiP, glucose-regulated protein 78/binding immunoglobulin protein; GluR2, ionotropic glutamate receptor 2.

We also examined the enriched fraction to determine if there were alterations in the expression of the AMPA receptor-interacting proteins, NSF, or SAP97. We found no significant change in the expression of NSF $(\mathrm{F}(1,35)=0.895, p=0.351) \quad$ or SAP97 $\quad(\mathrm{F}(1,38)=0.403$, $p=0.529)$ in our early endosome-enriched fraction (Figure 7). We found no significant associations with NSF/EEA1 or SAP97/EEA1 and medication status or sex.

\section{DISCUSSION}

Previous studies have attempted to link alterations in AMPA receptor trafficking with the underlying pathophyisology of schizophrenia. These studies have examined expression of polymorphisms, transcripts, and proteins associated with AMPA receptor forward trafficking (Beneyto and Meador-Woodruff, 2006; Scarr et al, 2005). Transcripts for the GluR2-interacting protein, GRIP1, were decreased in one study, but increased in another (Choi et al, 2002; Dracheva et al, 2005). A different study found no changes in GRIP1 protein expression in the frontal cortex (Toyooka et al, 2002). Binding site and protein expression of another AMPA trafficking molecule, NSF, was unchanged in the DLPFC (Beneyto and Meador-Woodruff, 2006; Gray et al, 2006; Imai et al, 2001), while another study found decreased SAP97 protein expression in the DLPFC, but not in the hippocampus or occipital cortex (Toyooka et al, 2002). In contrast to these studies, we found an increase in expression of two proteins associated with AMPA receptor trafficking, GRIP1 and SAP97 in the DLPFC. There are several possible explanations for these divergent results, including differences in western blot protocol, level of gene expression, subject age, or tissue source. For example, in one previous report (Toyooka et al, 2002), SAP97 was normalized to NSE, a neuronal cytoplasmic marker, while we used $\beta$-tubulin for normalization, a structural microtubule protein that is unchanged in schizophrenia (Bauer et al, 2009). In addition, the cohort in this study is elderly, while the subjects from other studies are generally younger. Regardless of the direction of change in expression, several studies have reported alterations in molecules associated with the trafficking of AMPA receptors in schizophrenia (McCullumsmith et al, 2004). Such alterations in trafficking proteins suggest abnormal trafficking of AMPA receptors along the dendrite and to the cell surface at the synapse. 

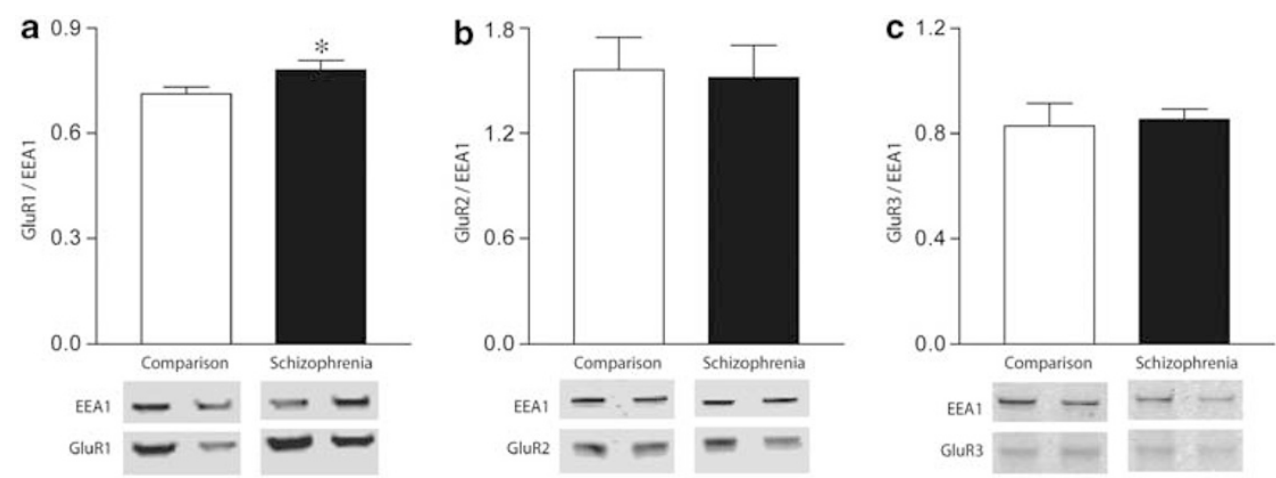

Figure 5 Western blot analysis of AMPA receptor subunits GluRI (a), GluR2 (b), and GluR3 (c) in early endosomes normalized to EEAI levels. Data are expressed as the ratio of subunit relative to isolated endosome expression. $* p<0.05$.

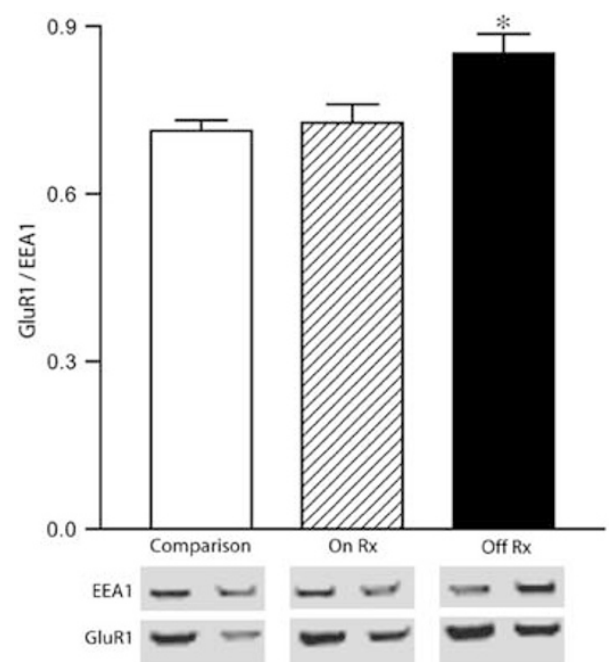

Figure 6 Analysis of antipsychotic effects on GluRI expression relative to expression of isolated early endosomes. Post hoc analysis of expression of GluRI relative to expression of isolated early endosomes. Patients on medication at time of death $(\mathrm{On} R x)$. Patients off medication for $\geqslant 6$ weeks at time of death $(\mathrm{Off} R \mathrm{R})$. * $p<0.05$.

To further understand AMPA receptor trafficking and its potential role in the pathophysiology of schizophrenia, we examined one subcellular fraction that is essential in the turnover of AMPA receptors at the cell surface, early endosomes. After endocytosis, endocytic vesicles fuse with early endosomes as the initial step in the sorting of receptors to recycling or late endosomes (Gruenberg, 2001; Hirling, 2008). The isolation protocol we developed provided intact early endosomes with no evidence of crosscontamination from other subcellular organelles. Isolated endosomes (Figure 3 ) were similar in size ( $\sim 1$ micron) and shape (spheroid) to descriptions of early endosomes in preclinical literature (Gruenberg, 2001; Tjelle et al, 1996). Further examination revealed that the AMPA receptor subunits GluR1, GluR2, and GluR3, as well as the AMPA receptor-interacting proteins, SAP97 and NSF, are present in the early endosomes in post-mortem brain tissue. Thus, we used this preparation to measure the contents of early endosomes in schizophrenia.

We found no change in total EEA1 protein expression, a marker of early endosomes, between the subjects with schizophrenia and our comparison group, suggesting that the total number of early endosomes is unchanged between the groups. We also found no change in expression of GluR1-3 in total homogenate, suggesting that there is not a problem with too much or too little AMPA receptor expression, but a problem with receptor trafficking. Western blot analysis of the isolated endosomes revealed an increase in GluR1 relative to EEA1 expression in subjects with schizophrenia. The increase in GluR1 protein expression in endosomes, combined with the increase in SAP97 and GRIP1 in homogenate, is consistent with increased forward trafficking of the subunit to the cell surface and an increase in endocytosis. Supporting these findings, we detected a significant positive correlation between SAP97 and GluR1 expression in tissue homogenates from subjects with schizophrenia, but not control subjects. We speculate that increased SAP97 might be a compensation for increased levels of GluR1 on the cell surface, with increased internalization of excess receptor complexes, in a manner similar to NMDA-induced LTD (Biou et al, 2008; Brown et al, 2005). Recent developments in the glutamate hypothesis of schizophrenia suggest that increased synaptic glutamate might contribute to pathophysiology in schizophrenia (Krystal, 2008). In preclinical studies, elevated synaptic glutamate levels led to a selective increase in the internalization of GluR1-containing AMPA receptors (Lissin et al, 1999). Such a mechanism is consistent with our findings of altered trafficking molecules and GluR1 in early endosomes and the hypothesis of increased synaptic glutamate in schizophrenia.

Alternatively, there may be dysfunction in the stabilization of GluR1-containing AMPA receptors at the synapse. The consequences of diminished levels of GluR1-containing AMPA receptors in the synapse have been examined in rodent models. One study using a GluR1 knockout mouse model found an increase in behavioral endophenotypes associated with schizophrenia (Wiedholz et al, 2008). Other studies have found removal of GluR1-containing AMPA receptors from the synapse leads to a decrease in LTP and cognitive dysfunction in rodents (Johnson et al, 2005; Mead and Stephens, 2003; Rumpel et al, 2005). If the GluR1containing receptors are not stabilized at the synapse, they may become trapped in the early endosomes. Regardless of the cause, our finding of increased GluR1 in early endosomes suggests abnormal intracellular localization of AMPA receptors in schizophrenia. 

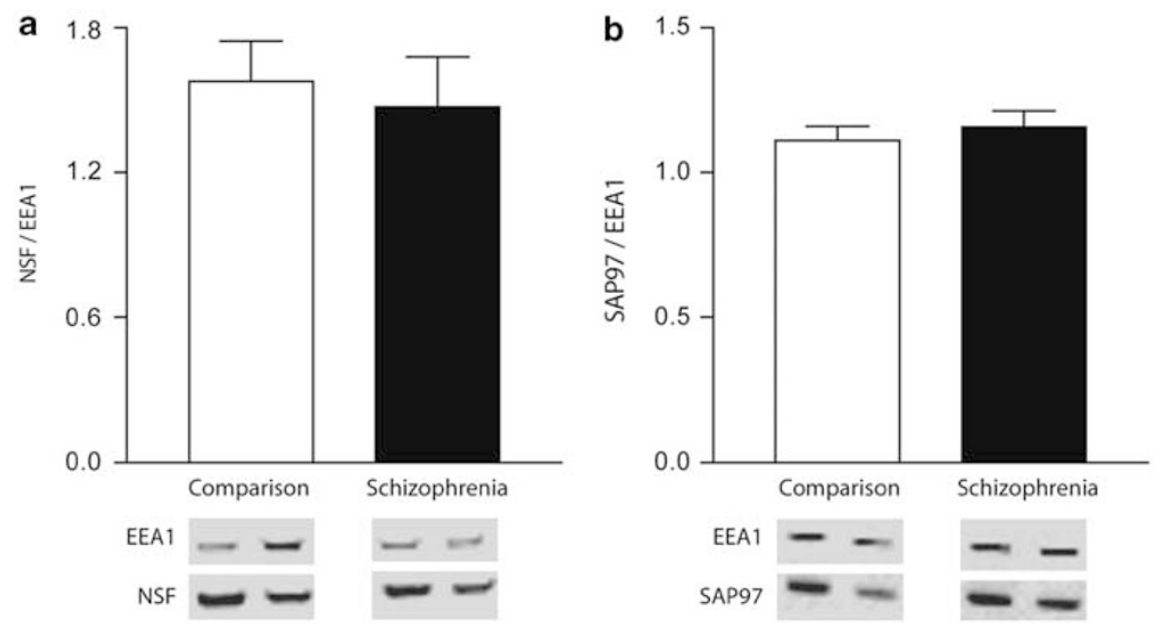

Figure 7 AMPA receptor-interacting protein expression in early endosomes. The expression of the AMPA receptor-interacting proteins, NSF (a) and SAP97 (b), relative to expression of EEAI was detected by western blot after enrichment of early endosomes.

Although GluR1 exists as part of a heteromeric AMPA receptor complex, we did not find an increase in other AMPA receptor subunits in the early endosomes. It may be that trafficking of GluR2- and GluR3-containing AMPA receptors through early endosomes is preserved in schizophrenia. To gain a clear understanding of where GluR2 and GluR3 may be localized, other subcellular fractions, including the ER and PSD, must be examined.

Many patients with schizophrenia have a long history of taking antipsychotic medication. To partially control for this effect, we examined a subset of subjects who were off medication for 6 weeks or more at the time of death. We found no medication-related changes in GluR2 or GluR3 in early endosomes, however, patients off medication had increased GluR1 protein expression in early endosomes relative to both the comparison group and the subjects on medication at the time of death (Figure 6). Thus, antipsychotic treatment may mask changes in AMPA receptor trafficking and localization, by decreasing the amount of GluR1-containing AMPA receptors that are present in early endosomes, without changing the overall protein expression level. In addition, there may be a neuroleptic effect on other trafficking molecules. However, this effect may be confined to the endosomes as we found no change in SAP97 or GRIP1 in early endosomes, in spite of a non-drug-related increase in these proteins in total homogenate. To further understand how drug-related changes affect trafficking, additional studies would be beneficial.

Although previous studies have examined surface binding of AMPA receptor subunits (Beneyto and Meador-Woodruff, 2006; Dracheva et al, 2005; Scarr et al, 2005), we have examined a subcellular compartment that directly contributes to the trafficking and surface expression of AMPA receptors. To isolate endosomes, we developed a modified immunoisolation protocol rather than using a standard subcellular fractionation technique involving high-speed centrifugation that may lead to cross-contamination of the fractions, because of the processing typically associated with post-mortem tissue collection (Aniento and Gruenberg, 2003; German and Howe, 2009). In addition, we found that when using magnetic or sepharose beads, there was nonspecific binding of some proteins to the beads, including PSD95. To remove this nonspecific binding, we found that a preclear step was required, highlighting the importance of appropriate control studies when using bead capture techniques in post-mortem tissue.

In summary, we found an increase in proteins involved in forward trafficking of AMPA receptors, SAP97 and GRIP1. This increase may lead to increased forward trafficking of the AMPA receptors and more AMPA receptors in the endosomal compartment. We also found an increase in an AMPA receptor subunit in early endosomes in the dorsolateral prefrontal cortex in schizophrenia, supporting the hypothesis that forward trafficking of AMPA receptors is altered in schizophrenia and suggesting that alterations in endosome contents may be associated with the underlying pathophyisology of the illness.

\section{ACKNOWLEDGEMENTS}

This work was supported by MH086257 (JCH), MH53327 (JMW), MH064673 and MH066392 (VH), and MH074016 and Doris Duke Clinical Scientist Award (REM). We would like to thank Basil Bakir for assistance with analysis of electron microscopy data.

\section{DISCLOSURE}

Dr James Meador-Woodruff receives an honorarium as editor of Neuropsychopharmacology. The remaining authors declare no conflict of interest.

\section{REFERENCES}

Allen R, Young S (1978). Phencyclidine-induced psychosis. Am J Psychiatry 135: 1081-1084.

Aniento F, Gruenberg J (2003). Subcellular fractionation of tissue culture cells. Curr Protoc Immunol Chapter 8: Unit 8.1C. 1-8.1C.21. Barbon A, Fumagalli F, La Via L, Caracciolo L, Racagni G, Riva M et al (2007). Chronic phencyclidine administration reduces the 
expression and editing of specific glutamate receptors in rat prefrontal cortex. Exp Neurol 208: 54-62.

Bauer D, Haroutunian V, McCullumsmith R, Meador-Woodruff J (2009). Expression of four housekeeping proteins in elderly patients with schizophrenia. J Neural Transm 116: 487-491.

Beattie E, Carroll R, Yu X, Morishita W, Yasuda H, von Zastrow M et al (2000). Regulation of AMPA receptor endocytosis by a signaling mechanism shared with LTD. Nat Neurosci 3: 1291-1300.

Beneyto M, Meador-Woodruff J (2006). Lamina-specific abnormalities of AMPA receptor trafficking and signaling molecule transcripts in the prefrontal cortex in schizophrenia. Synapse 60: 585-598.

Biou V, Bhattacharyya S, Malenka R (2008). Endocytosis and recycling of AMPA receptors lacking GluR2/3. Proc Natl Acad Sci USA 105: 1038-1043.

Boehm J, Kang M, Johnson R, Esteban J, Huganir R, Malinow R (2006). Synaptic incorporation of AMPA receptors during LTP is controlled by a PKC phosphorylation site on GluR1. Neuron 51: 213-225.

Bond D, Primrose D, Foley E (2008). Quantitative evaluation of signaling events in Drosophila s2 cells. Biol Proced Online 10: $20-28$.

Breese C, Freedman R, Leonard S (1995). Glutamate receptor subtype expression in human postmortem brain tissue from schizophrenics and alcohol abusers. Brain Res 674: 82-90.

Brown T, Tran I, Backos D, Esteban J (2005). NMDA receptordependent activation of the small GTPase Rab5 drives the removal of synaptic AMPA receptors during hippocampal LTD. Neuron 45: 81-94.

Carroll R, Beattie E, Xia H, Lüscher C, Altschuler Y, Nicoll R et al (1999). Dynamin-dependent endocytosis of ionotropic glutamate receptors. Proc Natl Acad Sci USA 96: 14112-14117.

Choi J, Ko J, Park E, Lee J, Yoon J, Lim S et al (2002). Phosphorylation of stargazin by protein kinase A regulates its interaction with PSD-95. J Biol Chem 277: 12359-12363.

Coyle J, Tsai G, Goff D (2003). Converging evidence of NMDA receptor hypofunction in the pathophysiology of schizophrenia. Ann NY Acad Sci 1003: 318-327.

Dracheva S, McGurk S, Haroutunian V (2005). mRNA expression of AMPA receptors and AMPA receptor binding proteins in the cerebral cortex of elderly schizophrenics. J Neurosci Res 79: 868-878.

Eastwood S, McDonald B, Burnet P, Beckwith J, Kerwin R, Harrison P (1995). Decreased expression of mRNAs encoding non-NMDA glutamate receptors GluR1 and GluR2 in medial temporal lobe neurons in schizophrenia. Brain Res Mol Brain Res 29: 211-223.

Ehlers M (2000). Reinsertion or degradation of AMPA receptors determined by activity-dependent endocytic sorting. Neuron 28: 511-525.

Ellison G (1995). The N-methyl-D-aspartate antagonists phencyclidine, ketamine and dizocilpine as both behavioral and anatomical models of the dementias. Brain Res Brain Res Rev 20: $250-267$.

Freed W, Dillon-Carter O, Kleinman J (1993). Properties of [3H]AMPA binding in postmortem human brain from psychotic subjects and controls: increases in caudate nucleus associated with suicide. Exp Neurol 121: 48-56.

Funk A, Rumbaugh G, Harotunian V, McCullumsmith R, Meador-Woodruff J (2009). Decreased expression of NMDA receptor-associated proteins in frontal cortex of elderly patients with schizophrenia. Neuroreport 20: 1019-1022.

Gerges N, Backos D, Esteban J (2004). Local control of AMPA receptor trafficking at the postsynaptic terminal by a small GTPase of the Rab family. J Biol Chem 279: 43870-43878.

German C, Howe C (2009). Preparation of biologically active subcellular fractions using the Balch homogenizer. Anal Biochem 394: 117-124.
Gray L, Scarr E, Dean B (2006). N-Ethylmaleimide sensitive factor in the cortex of subjects with schizophrenia and bipolar I disorder. Neurosci Lett 391: 112-115.

Greger I, Esteban J (2007). AMPA receptor biogenesis and trafficking. Curr Opin Neurobiol 17: 289-297.

Gruenberg J (2001). The endocytic pathway: a mosaic of domains. Nat Rev Mol Cell Biol 2: 721-730.

Guo L, Wang Y (2007). Glutamate stimulates glutamate receptor interacting protein 1 degradation by ubiquitin-proteasome system to regulate surface expression of GluR2. Neuroscience 145: $100-109$.

Healy D, Haroutunian V, Powchik P, Davidson M, Davis K, Watson $S$ et al (1998). AMPA receptor binding and subunit mRNA expression in prefrontal cortex and striatum of elderly schizophrenics. Neuropsychopharmacology 19: 278-286.

Hirling H (2008). Endosomal trafficking of AMPA-type glutamate receptors. Neuroscience 158: 38-44.

Imai C, Sugai T, Iritani S, Niizato K, Nakamura R, Makifuchi T et al (2001). A quantitative study on the expression of synapsin II and N-ethylmaleimide-sensitive fusion protein in schizophrenic patients. Neurosci Lett 305: 185-188.

Jiang J, Suppiramaniam V, Wooten M (2006). Posttranslational modifications and receptor-associated proteins in AMPA receptor trafficking and synaptic plasticity. Neurosignals 15: 266-282.

Johnson A, Bannerman D, Rawlins N, Sprengel R, Good M (2005). Impaired outcome-specific devaluation of instrumental responding in mice with a targeted deletion of the AMPA receptor glutamate receptor 1 subunit. J Neurosci 25: 2359-2365.

Krystal J (2008). Capitalizing on extrasynaptic glutamate neurotransmission to treat antipsychotic-resistant symptoms in schizophrenia. Biol Psychiatry 64: 358-360.

Lee S, Simonetta A, Sheng M (2004). Subunit rules governing the sorting of internalized AMPA receptors in hippocampal neurons. Neuron 43: 221-236.

Lissin D, Carroll R, Nicoll R, Malenka R, von Zastrow M (1999). Rapid, activation-induced redistribution of ionotropic glutamate receptors in cultured hippocampal neurons. J Neurosci 19: 1263-1272.

Lüscher C, Xia H, Beattie E, Carroll R, von Zastrow M, Malenka R et al (1999). Role of AMPA receptor cycling in synaptic transmission and plasticity. Neuron 24: 649-658.

McCullumsmith R, Clinton S, Meador-Woodruff J (2004). Schizophrenia as a disorder of neuroplasticity. Int Rev Neurobiol 59: $19-45$.

Mead A, Stephens D (2003). Selective disruption of stimulusreward learning in glutamate receptor grial knock-out mice. J Neurosci 23: 1041-1048.

Meador-Woodruff J, Hogg AJ, Smith R (2001). Striatal ionotropic glutamate receptor expression in schizophrenia, bipolar disorder, and major depressive disorder. Brain Res Bull 55: 631-640.

Mirnics K, Middleton F, Marquez A, Lewis D, Levitt P (2000). Molecular characterization of schizophrenia viewed by microarray analysis of gene expression in prefrontal cortex. Neuron 28: 53-67.

Nash J, Appleby V, Corrêa S, Wu H, Fitzjohn S, Garner C et al (2010). Disruption of the interaction between myosin VI and SAP97 is associated with a reduction in the number of AMPARs at hippocampal synapses. J Neurochem 112: 677-690.

Noel J, Ralph G, Pickard L, Williams J, Molnar E, Uney J et al (1999). Surface expression of AMPA receptors in hippocampal neurons is regulated by an NSF-dependent mechanism. Neuron 23: $365-376$.

Noga J, Hyde T, Bachus S, Herman M, Kleinman J (2001). AMPA receptor binding in the dorsolateral prefrontal cortex of schizophrenics and controls. Schizophr Res 48: 361-363. 
O'Connor J, Muly E, Arnold S, Hemby S (2007). AMPA receptor subunit and splice variant expression in the DLPFC of schizophrenic subjects and rhesus monkeys chronically administered antipsychotic drugs. Schizophr Res 90: 28-40.

Park M, Penick E, Edwards J, Kauer J, Ehlers M (2004). Recycling endosomes supply AMPA receptors for LTP. Science 305: 1972-1975.

Rumpel S, LeDoux J, Zador A, Malinow R (2005). Postsynaptic receptor trafficking underlying a form of associative learning. Science 308: 83-88.

Scarr E, Beneyto M, Meador-Woodruff J, Deans B (2005). Cortical glutamatergic markers in schizophrenia. Neuropsychopharmacology 30: 1521-1531.

Tjelle T, Brech A, Juvet L, Griffiths G, Berg T (1996). Isolation and characterization of early endosomes, late endosomes and terminal lysosomes: their role in protein degradation. J Cell Sci 109(Part 12): 2905-2914.
Toyooka K, Iritani S, Makifuchi T, Shirakawa O, Kitamura N, Maeda $\mathrm{K}$ et al (2002). Selective reduction of a PDZ protein, SAP-97, in the prefrontal cortex of patients with chronic schizophrenia. J Neurochem 83: 797-806.

Whiteheart S, Matveeva E (2004). Multiple binding proteins suggest diverse functions for the $\mathrm{N}$-ethylmaleimide sensitive factor. J Struct Biol 146: 32-43.

Wiedholz L, Owens W, Horton R, Feyder M, Karlsson R, Hefner K et al (2008). Mice lacking the AMPA GluR1 receptor exhibit striatal hyperdopaminergia and 'schizophrenia-related' behaviors. Mol Psychiatry 13: 631-640.

Wu H, Nash J, Zamorano P, Garner C (2002). Interaction of SAP97 with minus-end-directed actin motor myosin VI. Implications for AMPA receptor trafficking. J Biol Chem 277: 30928-30934.

Zhu J (2003). Mechanisms of synaptic plasticity: from membrane to intracellular AMPAR trafficking. Mol Interv 3: 15-18.

Supplementary Information accompanies the paper on the Neuropsychopharmacology website (http://www.nature.com/npp) 